\title{
Compound specific stable carbon isotopic signature of carbohydrate pyrolysis products from C3 and C4 plants (Py-CSIA)
}

José A. González-Pérez ${ }^{1}$, Nicasio T. Jiménez-Morillo ${ }^{1}$, José M. de la Rosa ${ }^{1}$, Gonzalo Almendros $^{2}$, Francisco-J. González-Vila ${ }^{1}$

1) IRNAS-CSIC, Av. Reina Mercedes, 10, 41012-Seville, Spain

2) MNCN-CSIC, c/Serrano 115-B, 28006-Madrid, Spain

*Corresponding author:

Tel +34954624711; Fax +34 954644002; e-mail jag@irnase.csic.es

This article has been accepted for publication and undergone full peer review but has not been through the copyediting, typesetting, pagination and proofreading process, which may lead to differences between this version and the Version of Record. Please cite this article as doi: 10.1002/jsfa.7169 


\begin{abstract}
BACKGROUND: Pyrolysis-compound specific isotopic analysis (Py-CSIA: Py-GC-(FID)-

C-IRMS) is a relatively novel technique that allows on-line quantitation of stable isotope proportions in chromatographically separated products released by pyrolysis. Validation of Py-CSIA technique is compulsory for molecular traceability in basic and applied research. In this work, commercial sucrose from C4- (sugarcane) and C3- (sugar beet) photosystem plants and admixtures, were studied using analytical pyrolysis (Py-GC/MS), bulk $\delta^{13} \mathrm{C}$ IRMS and $\delta^{13} \mathrm{C}$ Py-CSIA.

RESULTS: Major pyrolysis compounds were furfural (F), furfural-5-hydroxymethyl (HMF) and levoglucosan (LV). Bulk and main pyrolysis compound $\delta^{13} \mathrm{C}(\%)$ were dependent on plant origin: C3 (F: -24.65 \pm 0.89 ; HMF: $-22.07 \pm 0.41 \%$; LV: $-21.74 \pm 0.17 \%$.) and C4 (F: $14.35 \pm 0.89 \%$; HMF: $-11.22 \pm 0.54 \%$; LV $-11.44 \pm 1.26 \%$ ). Significant regressions were obtained for $\delta^{13} \mathrm{C}$ of bulk and pyrolysis compounds in $\mathrm{C} 3$ - and $\mathrm{C} 4$ admixtures. Furfural (F) was found ${ }^{13} \mathrm{C}$ depleted with respect to bulk and HMF and LV indicating the incorporation of the light carbon atom in position 6 of carbohydrates in the furan ring after pyrolysis.

CONCLUSION: This is the first detailed report on $\delta^{13} \mathrm{C}$ signature of major pyrolyticallygenerated carbohydrate-derived molecules. The information provided by Py-CSIA is valuable to identify source marker compounds of use in food science/fraud detection or in environmental research.
\end{abstract}

Keywords: Sucrose, analytical pyrolysis, stable carbon isotopes, furfural, furfural-5hydroxymethyl (HMF), levoglucosan 


\section{Introduction}

Analytical pyrolysis is defined as the thermochemical decomposition of organic materials at elevated temperatures in the absence of oxygen. ${ }^{1}$ The product of pyrolysis (pyrolysate) from most natural matrices in general consists of more or less complex mixtures of volatile products with specific precursors i.e. furans and pyranes from carbohydrates, methoxyphenols from lignins, and nitriles, pyrroles, and piperazines from proteins. ${ }^{2,3}$ This pyrolysate is amenable to chromatographic separation which, when combined with a mass spectrometry detector, yields a valid fingerprint information about the molecular structure even of complex mixtures of natural and synthetic macromolecular substances. ${ }^{4}$

On the other side, stable carbon isotope analysis consists on the measure of the quantitative assessment of the main stable isotopes of carbon $\left({ }^{12} \mathrm{C}\right.$ and $\left.{ }^{13} \mathrm{C}\right)$ in \%o relative to an international standard, viz., the fossil Pee Dee 1 belemnite $\left(\delta^{13} \mathrm{C}\right)$. This valuable tool with a wide range of applications in environmental sciences ${ }^{5}$ is also helpful in food traceability/fraud detection $^{6-9}$ as well as in forensic sciences. ${ }^{10,11} \mathrm{~A}$ well-known large differential $\delta^{13} \mathrm{C}$ value is that between plants in terms of its photosynthetic pathways: $\mathrm{C} 3, \mathrm{C} 4$ and crassulacean acid metabolism (CAM). Most terrestrial plants are $\mathrm{C} 3$ plants with $\delta^{13} \mathrm{C}$ values ranging from -24 to $-34 \%$, whereas many aquatic, desert and salt marsh plants as well as tropical grasses have the alkanedioic acid (C4) pathway and $\delta^{13} \mathrm{C}$ values ranging from -6 to $-19 \%{ }^{12}$ Plants with CAM have intermediate $\delta^{13} \mathrm{C}$ values typically in the range of -10 to $-20 \%$. ${ }^{13,14}$

Pyrolysis-compound specific isotopic analysis (Py-CSIA) is a relatively novel technique in which the volatile pyrolysis products (pyrolysate) are directed, through a combustion or pyrolysis interface, into an isotope ratio mass spectrometer to measure stable isotope 
proportions (i.e., $\delta^{13} \mathrm{C}, \delta \mathrm{D}, \delta^{18} \mathrm{O}, \delta^{15} \mathrm{~N}$ ) of specific compounds. A schematic typical configuration of a generic Py-GC-C-IRMS device can be found in Glaser (2005). ${ }^{15}$

Nowadays we know that the pyrolysis process does not produce appreciable fractionation of stable isotopes and therefore pyrolysis products are considered to be isotopically representative of the starting material ${ }^{16-18}$. Therefore this analytical pyrolysis hyphenated technique can provide valuable information (processes, origin and fingerprinting) about natural and synthetic materials. Since the first adaptation of the technique for $\delta^{13} \mathrm{C}$ by Goñi and Eglinton (1994) ${ }^{16}$, Py-CSIA has been successfully applied i.e. to determine molecular turnover times of major soil components including proteins and $\operatorname{lignin}^{19}$ to the characterization of dissolved organic matter in aquatic systems and bogs ${ }^{20,2} 1$ soil litter decay rates, ${ }^{22}$ wood components ${ }^{18}$, to discern vanillin origin ${ }^{23}$ or in the research on carbonaceous meteorites. $^{24}$

In this communication the stable isotope composition of the main compounds released by pyrolysis from commercial sugar samples synthesized by plants with differing photosystem systems, i.e., C4 sugarcane and C3 sugarbeet; were studied using conventional micro-furnace analytical pyrolysis, bulk stable isotopic analysis and pyrolysis compound specific stable isotopic analysis. 


\section{Materials and methods}

Commercial samples of sucrose from sugarcane and beet sugar purchased from ABF Group “Azucarera Española” (Madrid, Spain) were finely grounded in an agate mortar. Pure samples and mixtures of both sugar types $(20,40,60$ and $80 \%$ in dry weight) were prepared for analysis.

Conventional analytical pyrolysis (Py-GC/MS)

The direct pyrolysis-gas chromatography-mass spectrometry (Py-GC/MS) analysis was performed using a double-shot pyrolyzer (Frontier Laboratories, model 2020i) attached to a GC/MS system Agilent 6890N. Samples $0.5 \mathrm{mg}$ were placed in small crucible capsules and introduced into a preheated micro-furnace at $500{ }^{\circ} \mathrm{C}$ for $1 \mathrm{~min}$. The evolved gases were transferred into the GC/MS for analysis. The gas chromatograph was equipped with a low polar-fused silica (5\%-phenyl-methylpolysiloxane) capillary column Agilent J\&W HP-5ms

Ultra Inert, of $30 \mathrm{~m} \times 250 \mu \mathrm{m} \times 0.25 \mu \mathrm{m}$ film thickness The oven temperature was held at 50 ${ }^{\circ} \mathrm{C}$ for $1 \mathrm{~min}$ and then increased to $100^{\circ} \mathrm{C}$ at $30^{\circ} \mathrm{C} \min ^{-1}$, from $100{ }^{\circ} \mathrm{C}$ to $300{ }^{\circ} \mathrm{C}$ at $10{ }^{\circ} \mathrm{C}$ $\min ^{-1}$, and stabilized at $300{ }^{\circ} \mathrm{C}$ for 10 min using a heating rate of $20{ }^{\circ} \mathrm{C} \mathrm{min}^{-1}$ in the scan modus. The carrier gas used was helium at a controlled flow of $1 \mathrm{~mL} \mathrm{~min}{ }^{-1}$. The detector was an Agilent 5973 mass selective detector, and mass spectra were acquired at $70 \mathrm{eV}$ ionizing energy. Compound assignment was achieved via single-ion monitoring for various homologous series, via low-resolution mass spectrometry, and via comparison with published and stored (NIST and Wiley libraries) data. 
Bulk carbon stable isotopic analysis $\left(\delta^{13} C\right)$

Bulk isotopic signature of carbon $\left(\delta^{13} \mathrm{C}\right)$ was analysed using a Flash $2000 \mathrm{HT}(\mathrm{C}, \mathrm{H}, \mathrm{S})$ combustion (EA) elemental micro-analyser. The combustion tube was set at $1000{ }^{\circ} \mathrm{C}$ and sample size was $1.00 \mathrm{mg}$ wrapped in tin foil. The microanalyser was coupled via a ConFlo IV interface unit to a continuous flow Delta V Advantage isotope ratio mass spectrometer (IRMS) (Thermo Scientific, Bremen, Germany) (EA-IRMS). Isotopic ratios are reported as parts per thousand (\%o) deviations from appropriate standards recognized by the International Atomic Energy Agency (IAEA) ${ }^{25}$ The standard deviation of bulk $\delta^{13} \mathrm{C}$ was typically less than $\pm 0.05 \%$ relative to the appropriate recognized IAEA standards.

Pyrolysis compound specific isotopic analysis $\left(\delta^{13} C\right.$ Py-CSIA)

Direct pyrolysis compound specific isotopic analysis (Py-CSIA) of carbon $\left(\delta^{13} \mathrm{C}\right)$ was carried out with a double-shot pyrolyzer (Frontier Laboratories, model 3030D) attached to a GC/FID Trace GC Ultra system. At the end of the chromatographic column and in order to locate specific peaks within the chromatogram, the flux was divided and $10 \%$ diverted to the flame ionization detector (GC/FID) and 90\% to a GC-Isolink System equipped with a microfurnace for combustion set at $1020^{\circ} \mathrm{C}$ (EA) and coupled via a ConFlo IV universal interface unit to the Delta V Advantage IRMS (Py-GC-(FID)-C-IRMS).

Samples of $0.5 \mathrm{mg}$ were placed in small crucible capsules and introduced into the preheated pyrolyzer micro-furnace at $\left(500^{\circ} \mathrm{C}\right)$ for $1 \mathrm{~min}$. The evolved gases were then directly injected into the GC/FID/IRMS system for analysis. The gas chromatograph was equipped with a low polar-fused silica (5\%-phenyl-methylpolysiloxane) capillary column Agilent J\&W HP-5ms 
Ultra Inert, of $30 \mathrm{~m} \times 250 \mu \mathrm{m} \times 0.25 \mu \mathrm{m}$ film thickness. The oven temperature was held at 50 ${ }^{\circ} \mathrm{C}$ for $1 \mathrm{~min}$ and then increased to $100{ }^{\circ} \mathrm{C}$ at $30{ }^{\circ} \mathrm{C} \min ^{-1}$, from $100{ }^{\circ} \mathrm{C}$ to $300{ }^{\circ} \mathrm{C}$ at $10^{\circ} \mathrm{C}$ $\min ^{-1}$, and stabilized at $300{ }^{\circ} \mathrm{C}$ for 10 min using a heating rate of $20^{\circ} \mathrm{C} \mathrm{min}{ }^{-1}$. The carrier gas was helium at a controlled flow of $1 \mathrm{~mL} \mathrm{~min}^{-1}$.

Isotopic ratios for specific compounds are reported as parts per thousand (\%o) deviations from the appropriate standard (PDB) recognized by the IAEA. ${ }^{25}$ The standard deviations of compound specific $\delta^{13} \mathrm{C}$ was typically less than $\pm 0.1 \%$ relative to the IAEA standard. The identity of the compounds in the different chromatographic peaks were inferred by comparing and matching the mass spectra obtained by the conventional Py-GC/MS with the Py-GC/FID and Py-GC/IRMS chromatograms obtained using identical column and the same chromatographic conditions.

\section{Results and discussion}

Conventional analytical pyrolysis (Py-GC/MS)

The number and the total abundances of compounds released after the direct pyrolysis at 500 ${ }^{\circ} \mathrm{C}$ from both sucrose samples are very similar (Table 1 and Fig. 1) and no noticeable differences were detected between cane and beet sugar pyrograms. As expected, the majority of products released from the sucrose were typical carbohydrate-pyrolysis compounds ${ }^{3}$ i.e., furans, lactones (furanones), cyclic ketones (cyclopentanones) as well as anhydrosugars. A lignin marker (guaiacol) and a sulphur compound (dihydro-2-(3H)-thiophenone) was also present (Table 1). 
The conventional pyrograms were used as a source of structural information to later being able to assign $\mathrm{C}$ isotopic values to peaks of known compounds. This was done by matching Py-GC/MS chromatogram with that obtained with the flame ionization (Py-GC/FID) and the IRMS (Py-GC-C-IRMS) analysis as shown in the example in Fig. 2.

\section{Bulk $\delta^{13}$ C IRMS analysis}

Bulk C isotopic analysis for the two sucrose types (sugarbeet $\mathrm{C} 3$ and sugarcane $\mathrm{C} 4$ ) and its admixtures were measured. The expected differences in the bulk $\delta^{13} \mathrm{C}$ were found between the sugar from the main photosystem type plants: the $\mathrm{C} 3{ }^{13} \mathrm{C}$ depleted $(-22.82 \pm 0.44 \%$ ) and $\mathrm{C} 4{ }^{13} \mathrm{C}$ enriched $(-12.34 \pm 0.89 \%)$. A linear correlation with very significant fit $\left(R^{2}=0.988\right.$; $n=6$ ) was found between bulk $\delta^{13} \mathrm{C}$ and the $\%$ of mixture in the sample (Table 2 and Fig.3).

Compound specific isotopic analysis (Py-GC-(FID)-C-IRMS)

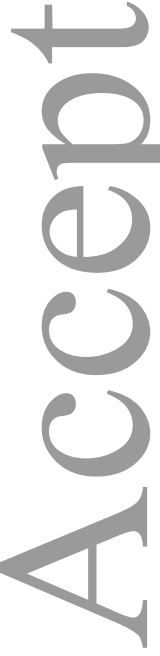

The main specific compounds released by pyrolysis were clearly identified in the FID and the IRMS chromatograms. To the best of our knowledge and taken into consideration not only peak size but also possible co-elutions inherent to the relatively complex pyrogram from sucrose, we confidently were able to assign structure and $\delta^{13} \mathrm{C}$ values for three major pyrolysis peaks for both cane and beet sugar: furfural (F), furfural-5-hydroxymethyl (HMF) and levoglucosan (LV). The above major three pyrolysis compounds represented $48.53 \%$ of cane sugar and $42.71 \%$ of beet sugar pyrolysis chromatographic area.

Again, the expected differences in the $\delta^{13} \mathrm{C}$ signatures between the sucrose from the plants with different photosystems were reflected by the diagnostic pyrolysis compounds: the $\mathrm{C} 3$ 
beet (F: $-24.65 \pm 0.89 \%$; HMF: $-22.07 \pm 0.41 \%$; LV: $-21.74 \pm 0.17 \%$ ) and the C4 sugarcane (F: $-14.35 \pm 0.89 \%$; HMF : $-11.22 \pm 0.54 \%$; LV -11.44 $\pm 1.26 \%$ ). As depicted in Fig. 3, outstanding significant linear regressions were also obtained when analysing the $\delta^{13} \mathrm{C}$ isotopic signature for the major sugar pyrolysis compounds in admixtures of beet and cane sugar $(20 \%, 40 \%, 60 \%, 80 \%$ and $100 \%)$.

Consistent isotopic fractionation $\left(\Delta \delta^{13} \mathrm{C}\right)$ was observed between the 5-carbons pyrolysis product (F), bulk and the other two sucrose derived structures with six C atoms (HMF \& LV). The highest difference was found between $\mathrm{F}$ and HMF the former being significantly ${ }^{13} \mathrm{C}$ depleted $\left(\Delta \delta^{13} \mathrm{C}_{\mathrm{F}-\mathrm{HMF}}=-2.54 \pm 0.97 \%\right.$ ). This isotopic difference may correspond to the known systematic ${ }^{13} \mathrm{C}$ depletion found for the carbon atom in position 6 of carbohydrates of both $\mathrm{C} 3$ and C4 type plants ${ }^{26,27}$. After the transformation of sucrose and pyrolysis-derived compounds (mainly dehydrogenation, dehydration, decarbonylation and decarboxylation), this light $\mathrm{C}$ is likely to remain Incorporated in the furan ring ${ }^{28}$ being responsible for this $\delta^{13} \mathrm{C}$ depletion observed in furfural (C5 structure).

This is a further confirmation that effectively furans released by pyrolysis effectively derive from carbohydrates retaining the original $\mathrm{C}$ isotopic signature. The fact that furfural retains the signature of the hydrocarbon light $\mathrm{C}$ in regard to isotope distributions in secondary plant products may have importance as a tool for food authenticity control and in monitoring plant physiological status. $^{29}$

The marker compounds F, HMF and LV are structures commonly found, not only in pyrolysates of sucrose, but also in a wide range of more complex organic materials that have a variable carbohydrate proportion i.e., natural fibres, woods, soils, peat and other organic 
deposits, compost, etc ${ }^{30-36}$. This technique could also be used in tetramethylammonium hydroxide (TMAH) thermochemolysis where a Py-GC/MS system is being employed to carry out thermally assisted hydrolysis (THM) in the presence of TMAH provided that the isotopic composition of the added methyl groups have been measured, e.g. carbohydrate THM products have been detected during the TMAH thermochemolysis of Sphagnum moss and peat ${ }^{36}$.

Our results indicate that pyrolysis compound specific isotopic analysis (Py-CSIA) can readily provide valuable information about the origin, composition, quality and even an accurate isotopic fingerprinting of foodstuffs. In addition this technique can be of use as a source of valid surrogates to organic matter origin and also, upon appropriate calibration and experimental designs, for the assessment of turn-over times - mainly for 'fast C pools'-in complex environmental matrices like soils, peats and sediments.

\section{Acknowledgements}

This work has been partly funded by the Spanish 'Ministerio de Economía y Competitividad' through project GEOFIRE (CGL2012-38655-C04-01). Dr. J.M. de la Rosa is the recipient of a fellowship from the JAE-Doc subprogram financed by the CSIC and the European Social Fund. 


\section{References}

1. Moldoveanu SC, Analytical pyrolysis of natural organic polymers. Techniques and Instrumentation in Analytical Chemistry 20: 3-496 (1998).

2. Gregorich EG, Monreal CM, Schnitzer M, Schulten H-R, Transformation of plant residues into soil organic matter: chemical characterization of plant tissue, isolated soil fractions and whole soils. Soil Sci 161: 680-693 (1996).

3. Almendros G, Dorado J, González-Vila FJ, Martin F, Pyrolysis of carbohydrate-derived macromolecules: its potential in monitoring the carbohydrate signature of geopolymers. $J$ Anal Appl Pyrolysis 40-41: 599-610 (1997).

4. González-Pérez JA, González-Vila FJ, Almendros G, Knicker H, De La Rosa JM, Hernández Z, Revisiting structural insights provided by analytical pyrolysis about humic substances and related bio-and geopolymers, in Functions of Natural Organic Matter in Changing Environment, ed. by Jianming X, Jianjun W, Yan H. Zhejiang University Press and Springer Science + Business Media, Dordrecht, pp. 1-5 (2013).

5. Michener R, Lajtha K, Stable Isotopes in Ecology and Environmental Science. Blackwell Publishing, Oxford, England. $2^{\text {nd }}$ Edition (2007).

6. White JW, Winters $\mathrm{K}$, Honey protein as international standard for stable isotope ratio detection of adulteration of honey. J AOAC Int 72: 907-911 (1989).

7. Kelly S, Parker I, Sharman M, Dennis J, Goodall I, Assessing the authenticity of single seed vegetable oils using fatty acid stable carbon isotope ratios $\left({ }^{13} \mathrm{C} /{ }^{12} \mathrm{C}\right)$. Food Chem 59: 181-186 (1997).

8. Rossmann A, Determination of stable isotope ratios in food analysis. Food Rev Int 17: 347-381 (2001). 
9. Karoui R, De Baerdemaeker J, A review of the analytical methods coupled with chemometric tools for the determination of the quality and identity of dairy products. Food Chem 102: 621-640 (2007).

10. Meier-Augenstein W, Applied gas chromatography coupled to isotope ratio mass spectrometry. J Chromatogr A 842: 351-371 (1999).

11. Benson S, Lennard C, Maynard P, Roux C, Forensic applications of isotope ratio mass spectrometry - A review. Forensic Sci Int 157: 1-22 (2006).

12. Deines $\mathrm{P}$, The isotopic composition of reduced organic carbon, in Handbook of Environmental Isotope Geochemistry, Vol 1, ed. by Fritz P, Fontes J C, Elsevier, New York, pp. 329-406 (1980).

13. Lüttge U, Ecophysiology of crassulacean acid metabolism (CAM). Ann Bot 93: 629-652 (2004).

14. Boom A, Carr AS, Chase BM, Grimes HL, Meadows ME, Leaf wax $n$-alkanes and $\delta^{13} \mathrm{C}$ values of CAM plants from arid Southwest Africa. Org Geochem 67: 99-102 (2014).

15. Glaser B, Compound-specific stable-isotope $\left(\delta^{13} \mathrm{C}\right)$ analysis in soil science. J Plant Nutr Soil Sci 168: 633-648 (2005).

16. Goñi MA, Eglinton TI, Analysis of kerogens and kerogen precursors by flash pyrolysis in combination with isotope-ratio-monitoring gas chromatography-mass spectrometry (irmGC-MS). J High Resolut Chromatogr 17: 476-488 (1994).

17. Corso TN, Brenna JT, High-precision position-specific isotope analysis. Proc Natl Acad Sci USA 94: 1049-1053 (1997).

18. Steinbeiss S, Schmidt CM, Heide K, Gleixner $\mathrm{G}, \delta^{13} \mathrm{C}$ values of pyrolysis products from cellulose and lignin represent the isotope content of their precursors. J Anal Appl Pyrolysis 75: 19-26 (2006). 
19. Gleixner G. Bol R. Balesdent J, Molecular insight into soil carbon turnover. Rapid Commun Mass Spectrom 13: 1278-1283 (1999).

20. Schulten H-R, Gleixner G, Analytical pyrolysis of humic substances and dissolved organic matter in aquatic systems: structure and origin. Water Res 33: 2489-2498 (1999).

21. Kracht O, Gleixner G, Isotope analysis of pyrolysis products from Sphagnum peat and dissolved organic matter from bog water. Org Geochem 31: 645-654 (2000).

22. Mambelli S., Bird JA, Gleixner G, Dawson TE, Torn MS, Relative contribution of foliar and fine root pine litter to the molecular composition of soil organic matter after in situ degradation. Org Geochem 42: 1099-1108 (2011).

23. Dennis MJ, Wilson P, Kelly S, Parker I, The use of pyrolytic techniques to estimate site specific isotope data of vanillin. J Anal Appl Pyrolysis 47: 95-103 (1998).

24. Sephton MA, Gilmour I, Pyrolysis-gas chromatography-isotope ratio mass spectrometry of macromolecular material in meteorites. Planet Space Sci 49: 465-471 (2001).

25. Valkiers S, Varlam M, Ruße K, Berglund M, Taylor P, Wang J, Milton M, De Bièvre P. Preparation of Synthetic Isotope Mixtures for the calibration of carbon and oxygen isotope ratio measurements (in carbon dioxide) to the SI. Int J Mass Spectrom 2 64: 1021 (2007).

26. Gilbert A, Robins RJ, Remaud GS, Tcherkez G, Intramolecular ${ }^{13} \mathrm{C}$ pattern in hexoses from autotrophic and heterotrophic C3 plant tissues. PNAS 109: 18204-18209 (2012).

27. Rossmann A, Butzenlechner M, Schmidt H-L, Evidence for a nonstatistical carbon Isotope distribution in natural glucose. Plant Physiol 96: 609-614 (1991).

28. Wang K, Kim KH, Brown RC, Catalytic pyrolysis of individual components of lignocellulosic biomass. Green Chem 16: 727-735 (2014).

29. Tcherkez G, Mahé A, Hodges $\mathrm{M},{ }^{12} \mathrm{C} /{ }^{13} \mathrm{C}$ fractionations in plant primary metabolism. Trends Plant Sci 16: 499-506 (2011). 
30. Arias ME, Rodríguez J, Pérez MI, Hernández M, Polvillo O, González-Pérez JA, González-Vila FJ, Analysis of chemical changes in Picea abies wood decayed by different Streptomyces strains showing evidence for biopulping procedures. Wood Sci Technol 44:179-188 (2010).

31. D'Antuono LF, Galletti GC, Bocchini P, Fiber quality of emmer (Triticum dicoccum Schubler) and einkorn wheat (T monococcum L) landraces as determined by analytical pyrolysis. J Sci Food Agric 78: 213-219 (1998).

32. Galetta MA, Reina L, Resquin F, Mantero C, González-Pérez JA, Almendros G, Menéndez MP, González-Vila FJ, Chemometric appraisal of lignin pyrolytic assemblages from Eucalyptus woods relevant for pulping in Uruguay. J Anal Appl Pyrolysis 109: 296303(2014).

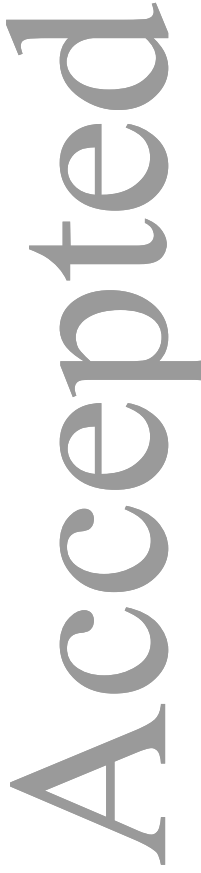

33. González-Pérez JA, Chabbi A, de la Rosa-Arranz JM, Rumpel C, González-Vila FJ, Evolution of organic matter in lignite-containing sediments revealed by analytical pyrolysis (Py-GC/MS). Org Geochem 53: 119-130 (2012).

34. González-Vila FJ, González-Pérez JA, Akdi K, Gómis MD, Pérez-Barrera F, Verdejo T, Assessing the efficiency of urban waste biocomposting by analytical pyrolysis (PyGC/MS). Bioresource Technol 100: 1304-1309 (2009).

35. Rumpel C, Rodríguez-Rodríguez A, González-Pérez JA, Arbelo C, Chabbi A, Nunan N, González-Vila FJ, Contrasting composition of free and mineral-bound organic matter in top- and subsoil horizons of Andosols. Biol Fert Soils 48: 401-411 (2012).

36. Abbott GD, Swain EY, Muhammad AB, Allton K, Belyea LR, Laing CG, Cowie GL. Effect of water-table fluctuations on the degradation of Sphagnum phenols in surficial peats. Geochim Cosmochim Acta 106: 177-191 (2013). 


\section{FIGURE CAPTIONS}

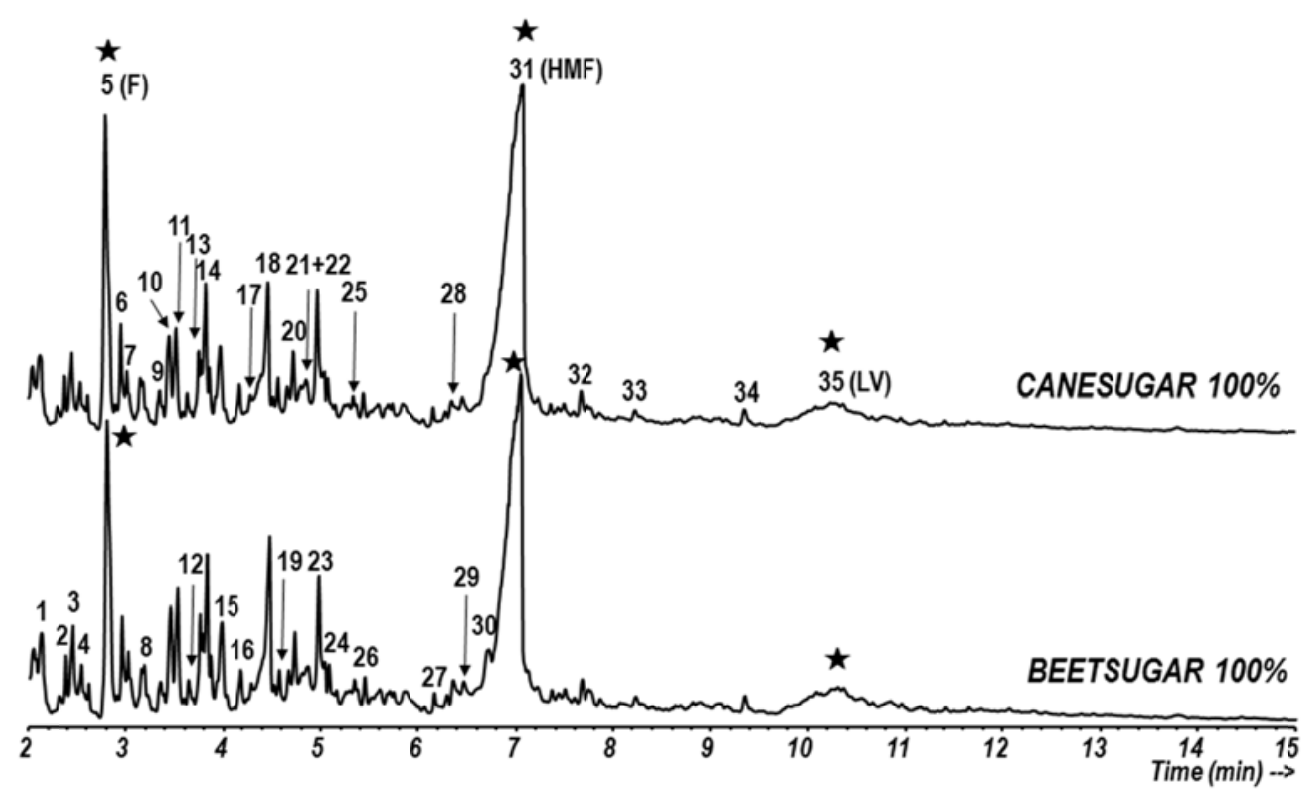

Figure 1 . Total ion chromatograms of the pyrolysis products released at $500{ }^{\circ} \mathrm{C}$ from beet and cane sugar (sucrose). Lettering on peaks refers to Table 1. Stars on traces indicate the major pyrolysis products for which C stable isotopic composition was measured. F: 2-

furancarboxaldehyde [furfural]; HMF: 2-furancarboxaldehyde, 5-(hydroxymethyl)[Hydroxymethylfurfural]; LV: 1,6-anhydro- $\beta$-D-glucopyranose [levoglucosan]. 


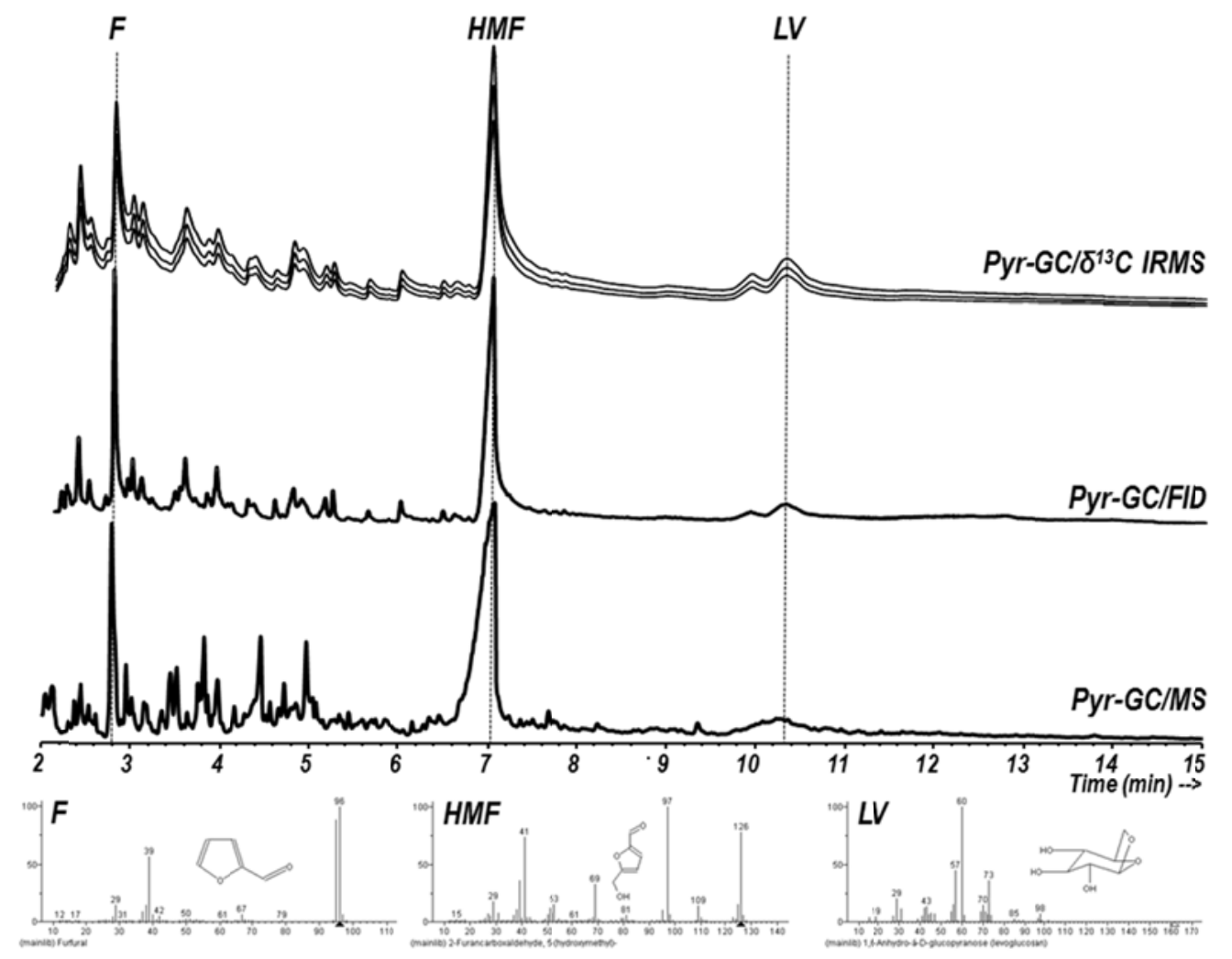

Figure 2. Matching sucrose Py-CSIA peaks with structural data. Chromatograms (pyrograms) from CSIA (Py-GC/ $\delta^{13} \mathrm{C}$ IRMS), flame ionization (Pyr-GC/FID) and mass spectrometry (PyGC/MS). The sample corresponds to pure sugarcane sucrose $(100 \% \mathrm{C} 4)$. F: 2furancarboxaldehyde [furfural]; HMF: 2-furancarboxaldehyde, 5-(hydroxymethyl)[hydroxymethylfurfural]; LV: 1,6-anhydro- $\beta$-D-glucopyranose [levoglucosan]. 


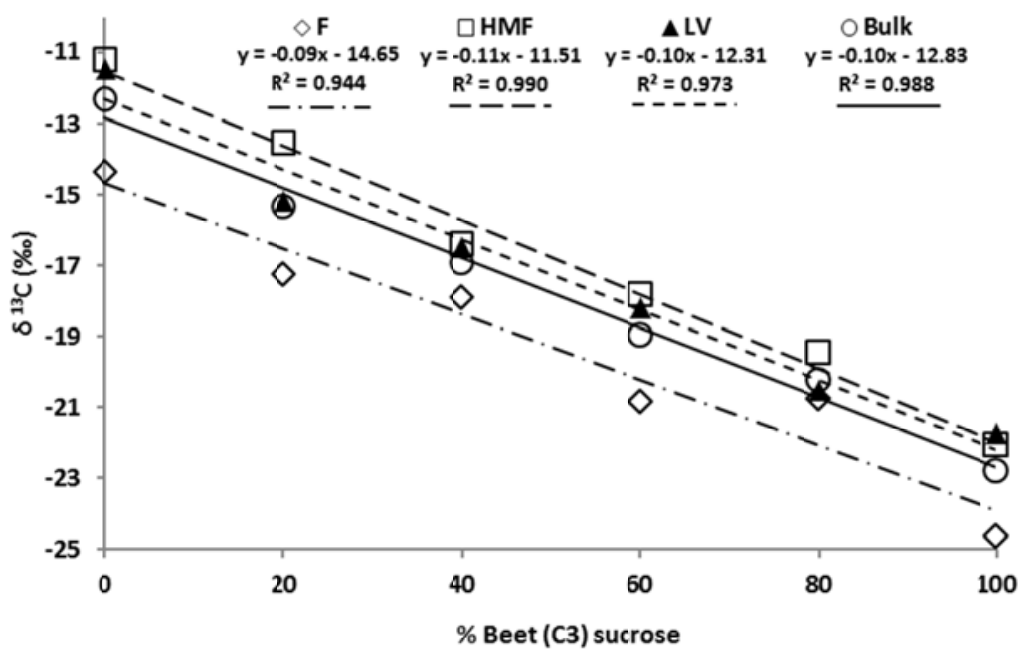

Figure 3.Isotopic signature of commercial sucrose from beet (C3) or sugarcane (C4) and their admixtures. Bulk and compound specific $\delta^{13} \mathrm{C}(\%)$ values and the corresponding regression lines. F: 2-furancarboxaldehyde [furfural]; HMF: 2-furancarboxaldehyde, 5(hydroxymethyl)- [hydroxymethylfurfural]; LV: 1,6-anhydro- $\beta$-D-glucopyranose [levoglucosan]. 


\section{TABLE CAPTIONS}

Table1. Total abundance of the main pyrolysis products released at $500{ }^{\circ} \mathrm{C}$ from beet and cane sugar (sucrose). Reference peak and retention time corresponds to labels in Fig.1.

Table1.

\begin{tabular}{|c|c|c|c|c|}
\hline Ref & $\begin{array}{c}\text { Ret } \\
\text { (min) }\end{array}$ & $\begin{array}{l}\text { Beet } \\
\text { (\%) }\end{array}$ & $\begin{array}{l}\text { Cane } \\
(\%)\end{array}$ & Compound \\
\hline 1 & 2.12 & 2.58 & 2.52 & Furan, 2,5-dimethyl- \\
\hline 2 & 2.37 & 0.91 & 0.88 & Butanal, 3-methyl- \\
\hline 3 & 2.44 & 2.06 & 1.80 & Propanoic acid, 2,2-dimethyl- \\
\hline 4 & 2.53 & 1.44 & 1.41 & Dihydro-2-(3H)-thiophenone \\
\hline 5 & 2.80 & 7.09 & 7.37 & Furfural \\
\hline 6 & 2.95 & 1.70 & 1.77 & 2-Furanmethanol \\
\hline 7 & 3.01 & 1.61 & 1.47 & 2-Propanone, 1-(acetyloxy)- \\
\hline 8 & 3.17 & 2.44 & 2.17 & 2-Cyclopentene-1,4-dione \\
\hline 9 & 3.34 & 1.12 & 1.17 & 2-Cyclopenten-1-one, 2-methyl- \\
\hline 10 & 3.44 & 2.33 & 2.11 & 2(5H)-Furanone \\
\hline 11 & 3.52 & 2.49 & 2.12 & 2(3H)-Furanone, 5-methyl- \\
\hline 12 & 3.63 & 1.04 & 0.98 & 2(5H)-Furanone, 5-methyl- \\
\hline 13 & 3.75 & 2.34 & 1.33 & 2-Butanone, 3,3-dimethyl- \\
\hline 14 & 3.82 & 2.52 & 2.96 & 2-Furancarboxaldehyde, 5-methyl- \\
\hline 15 & 3.97 & 3.14 & 2.85 & Propanoic acid, ethenyl ester \\
\hline 16 & 4.17 & 1.18 & 1.11 & Cyclopentanone, 2,5-dimethyl- \\
\hline 17 & 4.28 & 1.08 & 1.11 & 2,4-Dimethylcyclopent-4-ene-1,3-dione \\
\hline 18 & 4.47 & 5.77 & 5.15 & 2-Cyclopenten-1-one, 2-hydroxy-3-methyl- \\
\hline 19 & 4.56 & 1.06 & 1.10 & 2,3-Dimethyl-2-cyclopenten-1-one \\
\hline 20 & 4.72 & 1.66 & 1.52 & 3,5-Dimethylcyclopentenolone \\
\hline 21 & 4.80 & 1.01 & 1.03 & Phenol, 2-methoxy (guaiacol) \\
\hline 22 & 4.85 & 1.78 & 1.63 & Phenol, 3-methyl- \\
\hline 23 & 4.97 & 3.07 & 3.30 & 2,5-Furandicarboxaldehyde \\
\hline 24 & 5.07 & 1.18 & 1.19 & 2,3-Dihydro-5-hydroxy-6-methyl-4H-pyran-4-one \\
\hline 25 & 5.33 & 1.17 & 1.05 & 2-Butanone, 1-(2-furanyl)- \\
\hline 26 & 5.44 & 0.83 & 0.81 & 2-Cyclopenten-1-one, 3-ethyl-2-hydroxy- \\
\hline 27 & 6.16 & 0.84 & 0.59 & 1-(Dimethylfuranyl)-2-propanone \\
\hline 28 & 6.35 & 1.34 & 1.17 & 1,2-Benzenediol \\
\hline 29 & 6.46 & 1.54 & 1.38 & 3-Furancarboxylic acid, 2-methyl-, methyl ester \\
\hline 30 & 6.71 & 3.69 & 0.90 & 2-Furancarboxylic acid, methyl ester \\
\hline 31 & 7.04 & 27.40 & 34.25 & 2-Furancarboxaldehyde, 5-(hydroxymethyl)- \\
\hline 32 & 7.66 & 0.92 & 0.96 & 5-Acetoxymethyl-2-furaldehyde \\
\hline 33 & 8.22 & 0.67 & 1.12 & 1,4-Benzenediol, 2-methyl- \\
\hline 34 & 9.34 & 0.79 & 0.84 & 2,4-Octadienoic acid, 3-methyl-, methyl ester \\
\hline 35 & 10.30 & 8.22 & 6.91 & 1,6-Anhydro- $\beta$-D-glucopyranose (levoglucosan) \\
\hline
\end{tabular}


Table 2. Isotopic signature of commercial sucrose from beet (C3) or sugarcane (C4) and their admixtures. Bulk and compound specific $\delta^{13} \mathrm{C}(\%)$ values.

Table 2 .

\begin{tabular}{ccccc}
\hline $\begin{array}{c}\text { Mixture } \\
\text { (\% C3 sugar) }\end{array}$ & Bulk & F & HMF & LV \\
\hline $\mathbf{0}$ & $-12.34 \pm 0.89$ & $-14.35 \pm 0.89$ & $-11.22 \pm 0.54$ & $-11.44 \pm 1.26$ \\
$\mathbf{2 0}$ & $-15.33 \pm 1.86$ & $-17.26 \pm 0.37$ & $-13.55 \pm 0.20$ & $-15.18 \pm 0.00$ \\
$\mathbf{4 0}$ & $-16.93 \pm 0.85$ & $-17.91 \pm 0.36$ & $-16.42 \pm 0.11$ & $-16.47 \pm 0.09$ \\
$\mathbf{6 0}$ & $-18.95 \pm 1.66$ & $-20.86 \pm 0.42$ & $-17.82 \pm 0.12$ & $-18.19 \pm 0.27$ \\
$\mathbf{8 0}$ & $-20.24 \pm 0.67$ & $-20.75 \pm 0.36$ & $-19.48 \pm 0.86$ & $-20.51 \pm 0.46$ \\
$\mathbf{1 0 0}$ & $-22.82 \pm 0.44$ & $-24.65 \pm 0.76$ & $-22.07 \pm 0.41$ & $-21.74 \pm 0.17$ \\
\hline
\end{tabular}

F: 2-Furancarboxaldehyde [furfural]; HMF: 2-furancarboxaldehyde, 5-(hydroxymethyl)[Hydroxymethylfurfural]; LV: 1,6-Anhydro- $\beta$-D-glucopyranose [levoglucosan]. Values \pm $\operatorname{STD}(n=3)$ 